\title{
Energy Consumption and Green GDP in Europe: A Panel Cointegration Analysis 2008 - 2016
}

\author{
Marinko ŠKARE ${ }^{1 *}$, Daniel TOMIĆ ${ }^{2}$ and Saša STJEPANOVIĆ
}

Authors' affiliations and addresses: ${ }^{1}$ Juraj Dobrila University of Pula, Faculty of Economics and Tourism "Dr.Mijo Mirković, Preradovićeva 1/1,52100 Pula, Croatia e-mail: mskare@unipu.hr

${ }^{2}$ Juraj Dobrila University of Pula, Faculty of Economics and Tourism "Dr.Mijo Mirković, Preradovićeva 1/1,52100 Pula, Croatia e-mail: dtomic@unipu.hr

${ }^{3}$ Juraj Dobrila University of Pula, Faculty of Economics and Tourism "Dr.Mijo Mirković, Preradovićeva 1/1,52100 Pula, Croatia

e-mail: sstjepan@unipu.hr

\section{*Correspondence:}

Marinko Škare, Juraj Dobrila University of Pula, Faculty of Economics and Tourism "Dr.Mijo Mirković, Preradovićeva 1/1,52100 Pula, Croatia

Tel:+385 52377057

e-mail: mskare@unipu.hr

\section{Acknowledgement:}

This paper is a result of scientific - research projects "Accounting for the Future, Big Data and Economic Measurement" and "The

Determinants and Challenges of

Competitiveness" supported by the Faculty of Economics and Tourism "Dr. Mijo Mirkovićc", Juraj Dobrila University of Pula. Any opinions, findings, and conclusions or recommendations expressed in this paper are those of the author and do not necessarily reflect the views of the Faculty of Economics and Tourism "Dr. Mijo Mirković“", Pula.

How to cite this article:

Škare, M., Tomić, D. and Stjepanović, S. (2020). Energy Consumption and Green GDP in Europe: A Panel Cointegration Analysis 2008 - 2016. Acta Montanistica Slovaca, Volume 25 (1), 46-56

\section{DOI:}

https://doi.org/10.46544/AMS.v25i1.5

\begin{abstract}
The paper analyzes the relationship between energy consumption and green GDP as increased energy consumption could cause an increase in GDP. In order to evaluate how and to what extent the increase in energy consumption affects the size and movement of the green GDP, the aim of this paper is to confirm the existence of a strong link between energy consumption and green GDP. Having a large number of papers linking energy consumption and GDP, through this paper, we want to emphasize an even greater role of green GDP in energy consumption by linking the impact of the consumption of different energy sources with the movements in green GDP. Namely, how much different energy sources affect the gap between green GDP and GDP. Within the empirical analysis, we use a panel cointegration technique to examine long-term relationships among integrated variables. The data analyzed in this model cover 36 countries for the period from 2008 to 2016. These 36 countries include the EU28 countries and potential candidates for accession in the European Union. The results of our analysis follow the theory as we found that an increase in energy consumption causes an increase in GDP, hence the green GDP. However, the second part of the analysis suggests that an increase in consumption of energy in sectors that are environmentally more damaging emphasize the gap between the GDP and green GDP, but that an increase in more environmentally cleaner energy consumption curtails that gap.
\end{abstract}

\section{Keywords}

Green GDP, Panel cointegration, EU28, energy consumption.

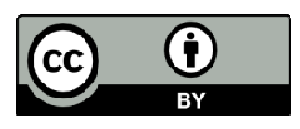

(C) 2020 by the authors. Submitted for possible open access publication under the terms and conditions of the Creative Commons Attribution (CC BY) license (http://creativecommons.org/licenses/by/4.0/). 


\section{Introduction}

This paper presents the relationship between energy consumption, GDP, and green GDP. Theoretically, any increase in energy consumption leads to an automatic increase in GDP. Based on a scarce number of papers related to green GDP - energy nexus, we analyze how much and in what way this energy consumption affects the movement of green GDP. Green GDP consists of several observed variables that negatively affect GDP and reduce it in a certain amount (Stjepanović, Tomić and Škare, 2019). It is usually calculated as traditional GDP minus the costs of environmental pollution and depletion of natural resources. Stjepanović, Tomić and Škare, (2017) provided us with a new green GDP measure that which was initially presented as a growth rate which makes it much easier to compare with traditional indicators. What makes this calculation of indicator stand out is that the authors carefully took and calculated the actual costs of environmental pollution and opportunity costs, and thus presented certain aspects of social costs. The result of this research brought us an alternative version of GDP that consisted of the variable waste production, CO2 emissions into the atmosphere, and consumption of natural resources. All these variables separately affect GDP and reduce it in a particular value as serious damage to the environment that will come to charge once. Through our paper, we want to analyze the true nature of the relationship between energy consumption from specific sources, like solid fuels or natural gas and green GDP. We expect that "greener" the energy source is, the smaller the negative impact on GDP should be, i.e., we should have a higher green GDP and vice versa. Our analysis, therefore, emphasizes various energy sources within today's high levels of pollution that has a huge impact on people as the environment is becoming a key economic issue. The shortcomings of GDP as a measure of a country's economic prosperity are pronounced today more than ever. One complaint is that GDP as a measure does not contain precise environmental components, and in that way only represents a deferred payment that will be paid by new generations. Therefore, it is necessary to include variables in the presentation of a country's economic progress and assess its impact on GDP, which are, in fact, related to the environment and sustainable development. Only then can we have a more objective measure that will evaluate economic progress from a different angle and on which we can assess better the efficiency and success of a country's economic system. After the introduction, we present a summary of the energy consumption and growth research.

The goal of this paper is to study the relationship between green GDP and GDP, using the energy consumption variables. Although there are papers that have dealt with similar topics, but only for one country, the emphasis of this paper is to study the European countries. By analyzing these countries, we will come to a conclusion about the impact of separate energy sources on green GDP. The gap between green GDP should be smaller in those countries that use less harmful energy sources for the environment, and larger for those countries that use more harmful energy sources. Particular emphasis is placed on renewable energy sources and their impact on Green GDP. In our analysis, we use annual panel data covering the period 2008-2016 for 36 European countries. Countries involved in the analysis are EU 28 countries plus other European countries (Iceland, Norway, Montenegro, North Macedonia, Albania, Serbia, Turkey, and Moldova). Hence, our presumption about homogenous data sample suggests that the panel data approach should be an appropriate method for analyzing this relationship. We explain the data and methods in the next section and discuss the results of the study in the results section. Finally, we conclude by giving a summary of remarks and facts in conclusion.

\section{Literature Review}

The motive of this paper is to extend previous researches on this or similar topics. Here are some papers that tried to link energy consumption and green GDP. One such paper that seeks to reveal the background of the relationship between energy consumption growth and green GDP growth for China is a paper (Hongxian, 2018), entitled "Influence energy consumption has on green GDP growth in China". In this paper, the author analyzes the direct and indirect impact on the growth rate of green GDP, which affects several ratios of energy consumption as well as the relationship between different energy sources. Likewise, (Al-mulali, 2014), in his paper, describes the association of GDP growth with energy consumption. The purpose of this paper was to investigate the relationship between gross domestic product growth and renewable and independent energy consumption in 82 developing countries. One of the papers that analyzed the relationship between green GDP and sustainable development is the paper (Vaghefi, Siwar, and Aziz, 2015), which provides evidence of the usefulness of alternative measures of GDP, i.e., green GDP. The authors calculated green GDP for Malaysia and indicated the important role of depleted natural resources and environmental damage within the country's sustainable development perspective. The problem of calculating green GDP is also studied by Wang, He and Zheng (2014), who describe the way in which the Green GDP system was designed and developed for China. The results suggested that China has not achieved 'clean 'economic growth, due to excessive pollution and too high utilization of natural resources. The authors concluded that this research confirm the status quo of China's 
current economic development. Similar papers as that of the authors (Harnphatananusorn, Santipolvut, and Sonthi, 2019), speak of correction of GDP - for the amount it produces for air pollution and water pollution.

Strong global growth we see in the $20^{\text {th }}$ and $21^{\text {st }}$ century demands significant energy consumption. Energy is considered a complementary growth factor to the physical factor. According to the study by Malaczewski (2018), there is an optimal (golden point) of energy consumption proportional to the optimal combination between human and physical capital. Energy production and innovation are directly linked to carbon dioxide emissions (CO2e). Present economic growth models show over-dependency on carbon-intensive energy consumption (Rahman et al., 2019). Renewable energy use demands large support schemes to develop an efficient bio market, leading to an increase in investment efficiency and energy transformation (Gavurova et al., 2016).

World energy demand constantly increases and by 2050 is expected to reach $600-1500$ EJ. year- ${ }^{1}$ and peak in 2100 with $900-3600$ EJ. year $^{-1}$ (Kovács, 2007). Speeding urbanization is causing upward pressure to the energy consumption, and thus $\mathrm{CO} 2$ emission requires to re-evaluate current economic growth models if the upward trend of urbanization continues (Yazdi and Dariani, 2019). Study of Katarína et al., (2014) suggests that investments in renewable energy sources register higher efficiency and are limited by political, economic, administrative and legal constraints. Transformation to green economic growth models require significant public support since investments in renewable energy sources will remain unattractive for many years to come (Sokolovska and Kešeljević, 2019).

Transition to green economic growth models is possible and feasible. It demands strong public support schemes accompanied by consistent energy conservation policy assuring endogenous growth in the future (Faisal et al., 2018). There is a strong need to explore the link between energy consumption and future economic growth models.

\section{Data and Methodology}

Annual panel data, covering the period 2008-2016 for 36 European countries, are taken from the Eurostat database. The data for green GDP are from the study Stjepanović, Tomić and Škare (2019) using an alternative approach in measuring the green GDP (Stjepanović, Tomić and Škare, 2017). Data are expressed in logarithms and presented as $\operatorname{lnGGDP}$ as the logarithm of the green GDP indicator, lnGAP as the logarithm of the gap from green GDP to standard GDP measure, InENERG as the logarithm of total energy consumption, lnFFUEL as the logarithm of solid fossil fuel consumption, lnNGAS as the logarithm of natural gas consumption, InOIL as the logarithm of oil and petroleum consumption and lnRENEW as the logarithm of renewable and biofuel consumption, so that the energy consumption variables are expressed as a thousand tonnes of oil equivalent (TOE). Countries involved in the analysis are EU 28 countries (UK was still a part of the EU) plus other European countries (Iceland, Norway, Montenegro, North Macedonia, Albania, Serbia, Turkey, and Moldova). The logical presumption about homogeneity among European countries suggests that the panel data approach should be an appropriate method for replying to our research question; thus, this presumption will be evaluated through the results.

Cointegration analysis with panel data usually consists of unit root tests, cointegration tests, and the estimation of long-run (and short-run) relationship. For that purpose, we applied research logic and explanations from the paper from Škare, Benazić, and Tomić (2016). The panel analysis begins with panel unit root tests to avoid possible spurious results. If the series are non-stationary, the analysis continues with testing for the panel cointegration. Following the panel, unit root tests are used in this research: LLC test (Levin, Lin and Chu, 2002), Breitung test (Breitung, 2000), IPS test (Im, Pesaran and Shin, 2003), Fisher-type tests using ADF and PP tests (Maddala and Wu, 1999 and Choi, 2001) and Hadri test (Hadri, 2000).

Next, we evaluated panel cointegration tests, according to Pedroni (1999, 2004), Kao (1999) and Maddala and $\mathrm{Wu}$ (1999). Pedroni and Kao extend the two-step Engle-Granger (1987) framework to tests involving panel data. Pedroni introduced several tests for cointegration that allow for heterogeneous intercepts and trend coefficients across cross-sections. The Kao test follows the same approach but indicates cross-section specific intercepts and homogeneous coefficients on the first-stage regressors. Maddala and Wu (1999) applied Fisher's combined test that uses the results of the individual independent tests and Johansen's test methodology as an alternative approach that combines the tests from individual cross-sections in order to obtain test statistics for the full panel.

The long-run relationship is estimated using the pooled Panel Fully Modified Least Squares (FMOLS), pooled Panel Dynamic Least Squares (DOLS) and Pooled Mean Group/AR Distributed Lag (PMG/ARDL) estimation methods. Since FMOLS and DOLS provide only long-run estimates, for the short-run estimation, PMG/ARDL is used. Phillips and Moon (1999), Pedroni (2000), and Kao and Chiang (2000) proposed extensions of the Phillips and Hansen (1990) FMOLS estimator to panel settings while Kao and Chiang (2000), and Pedroni (2001) propose extensions of the Saikkonen (1992) and Stock and Watson (1993) DOLS estimator. FMOLS and DOLS estimation methods for panel settings allow the estimation of panel cointegrating regression 
equation for non-stationary data by correcting the standard pooled OLS for serial correlation and endogeneity of regressors that are usually present in long-run relationships. The PMG/ARDL (Pesaran, Shin and Smith, 1999) takes the cointegration form of the simple ARDL model and adapts it for a panel setting by allowing the intercepts, short-run coefficients and cointegrating terms to differ across cross-sections.

To comprehend the influence of energy consumption towards the green GDP, we divide our analysis into two parts; one is dealing with the direct nexus between the green GDP and total energy consumption and the other dealing with an indirect link between the green GDP and the elements of energy consumption that comprise the total energy consumption. The direct effect is, analyzed in a twofold manner; (1) by observing the direct influence of the energy consumption on the green GDP indicator (as we expect that the rise in energy consumption should drive the standard GDP, hence the green GDP) and (2) by observing the direct influence of the energy consumption on the gap GDP indicator as the measure that reveals the bias of the standard GDP towards the green GDP (we expect that the rise in energy consumption should increase the difference between two measures). Two equations can represent these effects:

$$
\begin{array}{ll}
\operatorname{lnGGDP}_{\text {it }}=\alpha_{0 \mathrm{i}}+\beta_{1 \mathrm{i}} \operatorname{lnENERG}_{\text {it }}+\mathrm{u}_{\mathrm{it}}, & \mathrm{i}=1,2, \mathrm{~K}, \mathrm{~N}, \mathrm{t}=1,2, \mathrm{~K}, \mathrm{~T} \\
\operatorname{lnGAP}_{\mathrm{it}}=\alpha_{0 \mathrm{i}}+\beta_{1 \mathrm{i}} \operatorname{lnENERG}_{\mathrm{it}}+\mathrm{u}_{\mathrm{it}}, & \mathrm{i}=1,2, \mathrm{~K}, \mathrm{~N}, \mathrm{t}=1,2, \mathrm{~K}, \mathrm{~T}
\end{array}
$$

where $\operatorname{lnGGDP}_{\text {it }}$ represents the logarithm of green GDP at time $t, \operatorname{lnGAP}$ it represents the logarithm of the gap between the green GDP and standard GDP indicator at time t, lnENERG $\mathrm{it}_{\text {it }}$ stands for total energy consumption at time $t$, and uit is the error term while $i$ and tenote country and time respectively.

Since the energy consumption variable is expected to increase the green GDP indicator, through indirect effect, we are trying to grasp the background of that relationship by observing how some parts, which the energy consumption indicator is composed of, influence the green GDP, i.e. do specific parts of the energy consumption deepen or curtail the difference between the GDP measure and the green GDP measure. This bond can be, therefore expressed as:

$$
\begin{gathered}
\operatorname{lnGAP}_{\mathrm{it}}=\alpha_{0} \mathrm{i}+\beta_{1 \mathrm{i}} \operatorname{lnFFUEL}_{\mathrm{it}}+\beta_{2 \mathrm{i}} \operatorname{lnNGAS}_{\mathrm{it}}+\beta_{3 \mathrm{i}} \operatorname{lnOIL}_{\mathrm{it}}+\beta_{4 \mathrm{i}} \operatorname{lnRENEW}_{\mathrm{it}}+\mathrm{u}_{\mathrm{it}}, \\
\mathrm{i}=1,2, \mathrm{~K}, \mathrm{~N}, \mathrm{t}=1,2, \mathrm{~K}, \mathrm{~T}
\end{gathered}
$$

where $\operatorname{lnGAP}_{\text {it }}$ again represents the logarithm of the gap between the green GDP and standard GDP indicator at time $t, \operatorname{lnFFUEL}_{i t}$ stands for fossil fuel consumption at time $t, \operatorname{lnNGAS} S_{i t}$ stands for natural gas consumption at time $t, \operatorname{lnOIL}_{i t}$ stands for oil and petroleum consumption at time $t, \operatorname{lnRENEW}_{\text {it }}$ stands for renewable and biofuel consumption at time $\mathrm{t}$, and $\mathrm{u}_{\mathrm{it}}$ is the error term while $\mathrm{i}$ and $\mathrm{t}$ denote country and time respectively.

\section{Panel cointegration results}

Regarding the order of integration of our time series, unit root tests indicated that the variables are integrated, i.e. they are non-stationary in level and stationary in first differences (results available upon request). Therefore, a panel cointegration test can be implemented. The following tables present the results of both the direct and indirect effect of energy consumption on the green GDP.

\section{a) direct effect}

The results from Pedroni's, Kao's and Johansen Fisher's panel cointegration tests were evaluated for both, equation 1 and equation 2, suggesting that there indeed exists a long-term (direct) relationship between the green GDP and energy consumption as well as between the gap GDP and energy consumption.

In both cases, with only intercept and again when intercept and trend are included, most of the Pedroni's statistics reject the null hypothesis of no cointegration between variables indicating the existence of long-run panel cointegration relationship between the observed variables (Table 1). Thus, it can be concluded that there exists a long-run relationship. Kao's panel cointegration test also strongly rejects the null hypothesis of no cointegration between variables indicating the existence of a long-run panel cointegration relationship between the observed variables (Table 2). 
Table 1: Pedroni residual cointegration test

\begin{tabular}{|c|c|c|c|c|c|c|c|c|}
\hline \multicolumn{9}{|c|}{ Variables: lnGGDP, lnENERG } \\
\hline & \multicolumn{4}{|c|}{ Intercept } & \multicolumn{4}{|c|}{ Intercept and trend } \\
\hline & Statistic & Prob. & $\begin{array}{l}\text { Weighted } \\
\text { Statistic }\end{array}$ & Prob. & Statistic & Prob. & $\begin{array}{c}\text { Weighted } \\
\text { Statistic }\end{array}$ & Prob. \\
\hline Panel v-Statistic & 0.47 & 0.32 & -1.66 & 0.95 & -3.39 & 0.99 & -5.81 & 1.00 \\
\hline Panel rho-Statistic & -1.39 & 0.08 & -1.89 & 0.03 & 1.43 & 0.92 & -1.30 & 0.90 \\
\hline Panel PP-Statistic & -4.90 & 0.00 & -6.56 & 0.00 & -6.71 & 0.00 & -8.69 & 0.00 \\
\hline Panel ADF-Statistic & -4.80 & 0.00 & -5.01 & 0.00 & -5.25 & 0.00 & 5.67 & 0.00 \\
\hline Group rho-Statistic & 1.45 & 0.93 & & & 3.53 & 0.99 & & \\
\hline Group PP-Statistic & -6.99 & 0.00 & & & -15.22 & 0.00 & & \\
\hline Group ADF-Statistic & -5.58 & 0.00 & & & -8.25 & 0.00 & & \\
\hline \multicolumn{9}{|c|}{ Variables: InGAP, InENERG } \\
\hline & \multicolumn{4}{|c|}{ Intercept } & \multicolumn{4}{|c|}{ Intercept and trend } \\
\hline & Statistic & Prob. & $\begin{array}{c}\text { Weighted } \\
\text { Statistic }\end{array}$ & Prob. & Statistic & Prob. & $\begin{array}{c}\text { Weighted } \\
\text { Statistic }\end{array}$ & Prob. \\
\hline Panel v-Statistic & -0.08 & 0.53 & -1.29 & 0.90 & -3.29 & 0.99 & -5.21 & 1.00 \\
\hline Panel rho-Statistic & 0.24 & 0.60 & 0.15 & 0.56 & 3.80 & 0.99 & 3.44 & 0.99 \\
\hline Panel PP-Statistic & -2.09 & 0.02 & -3.47 & 0.00 & -1.87 & 0.03 & -4.88 & 0.00 \\
\hline Panel ADF-Statistic & -4.81 & 0.00 & -6.79 & 0.00 & -7.27 & 0.00 & -8.31 & 0.00 \\
\hline Group rho-Statistic & 2.97 & 0.99 & & & 5.25 & 1.00 & & \\
\hline Group PP-Statistic & -4.19 & 0.00 & & & -6.51 & 0.00 & & \\
\hline Group ADF-Statistic & -8.80 & 0.00 & & & -8.15 & 0.00 & & \\
\hline
\end{tabular}

Source: Authors' calculations.

\begin{tabular}{ccc} 
Table 2: Kao residual cointegration test (individual intercept) \\
\hline \multirow{2}{*}{ ADF } \\
\cline { 2 - 3 } Variables & t-Statistic & Prob. \\
lnGGDP, lnENERG & -0.62 & 0.27 \\
lnGAP, lnENERG & -2.43 & 0.01 \\
\hline
\end{tabular}

Source: Authors' calculations.

Finally, Johansen Fisher trace and maximum eigenvalue cointegration tests reject the null hypothesis of no cointegration between variables indicating the existence of long-run panel cointegration relationship between the green GDP and energy consumption, and gap GDP variable and energy consumption (Table 3). According to these results, energy consumption could affect both green GDP variables in the long-run. Individual crosssection results (available upon request) suggest that one cointegration relation is present in almost all countries, either in the case with restricted or unrestricted constant.

Table 3: Johansen Fisher panel cointegration test (Trace and Maximum Eigenvalue)

\begin{tabular}{|c|c|c|c|c|c|c|c|c|}
\hline \multicolumn{9}{|c|}{ Variables: $\ln \boldsymbol{G} \boldsymbol{G D P}, \ln \boldsymbol{E} \boldsymbol{N E R} \boldsymbol{G}$} \\
\hline \multirow{2}{*}{$\begin{array}{l}\text { Hypothesized } \\
\text { No. of CE }(s)\end{array}$} & \multicolumn{4}{|c|}{ No deterministic trend (restricted constant) } & \multicolumn{4}{|c|}{ Linear deterministic trend (unrestricted constant) } \\
\hline & Fisher Stat.* & Prob. & Fisher Stat. $* *$ & Prob. & Fisher Stat. * & Prob. & Fisher Stat. $* *$ & Prob. \\
\hline None & 443.90 & 0.00 & 448.50 & 0.00 & 4478.00 & 0.00 & 623.10 & 0.00 \\
\hline At most 1 & 117.80 & 0.00 & 115.2 & 0.00 & 166.60 & 0.00 & 166.60 & 0.00 \\
\hline \multicolumn{9}{|c|}{ Variables: $\ln \boldsymbol{G A P}, \boldsymbol{l n} \boldsymbol{E} \boldsymbol{N E R} \boldsymbol{G}$} \\
\hline Hypothesized & \multicolumn{4}{|c|}{ No deterministic trend (restricted constant) } & \multicolumn{4}{|c|}{ Linear deterministic trend (unrestricted constant) } \\
\hline No. of $C E(s)$ & Fisher Stat.* & Prob. & Fisher Stat. $* *$ & Prob. & Fisher Stat.* & Prob. & Fisher Stat. $* *$ & Prob. \\
\hline None & 565.10 & 0.00 & 515.90 & 0.00 & 4478.00 & 0.00 & 623.10 & 0.00 \\
\hline At most 1 & 192.00 & 0.00 & 192.00 & 0.00 & 293.30 & 0.00 & 293.30 & 0.00 \\
\hline
\end{tabular}

The following tables present the panel cointegration results from FMOLS, DOLS and PMG/ARDL estimation methods between the observed variables, testing the validity long-run linear cointegration relations. 
Table 4: Panel cointegration results (Pooled estimation) - $\ln G G D P, \ln E N E R G$

\begin{tabular}{|c|c|c|c|c|c|c|c|c|}
\hline \multicolumn{9}{|c|}{ Panel Fully Modified Least Squares (FMOLS) } \\
\hline \multirow[b]{2}{*}{ Variable } & \multicolumn{4}{|c|}{ Constant } & \multicolumn{4}{|c|}{ Constant and trend } \\
\hline & Coefficient & Std. Error & t-Statistic & Prob. & Coefficient & Std. Error & t-Statistic & Prob. \\
\hline InENERG & 0.12 & 0.04 & 3.48 & 0.00 & 0.07 & 0.03 & 2.05 & 0.04 \\
\hline \multicolumn{9}{|c|}{ Panel Dynamic Least Squares (DOLS) } \\
\hline \multirow{2}{*}{ Variable } & \multicolumn{4}{|c|}{ Constant $(1,1)$} & \multicolumn{4}{|c|}{ Constant and trend $(0,0)$} \\
\hline & Coefficient & Std. Error & t-Statistic & Prob. & Coefficient & Std. Error & t-Statistic & Prob. \\
\hline InENERG & 0.70 & 0.17 & 4.11 & 0.00 & 0.13 & 0.03 & 3.92 & 0.00 \\
\hline \multicolumn{9}{|c|}{ PMG/ARDL (Pooled Mean Group/AR Distributed Lag) - ARDL $(1,1)$} \\
\hline \multirow{3}{*}{ Variable } & \multicolumn{4}{|c|}{ Restricted constant } & \multicolumn{4}{|c|}{ Unrestricted constant } \\
\hline & Coefficient & Std. Error & t-Statistic & Prob. & Coefficient & Std. Error & t-Statistic & Prob. \\
\hline & & & & ong $\mathrm{Ru}$ & Equation & & & \\
\hline \multirow[t]{2}{*}{ InENERG } & 0.82 & 0.09 & 9.38 & 0.00 & -0.24 & 0.05 & -4.41 & 0.00 \\
\hline & \multicolumn{8}{|c|}{ Short Run Equation } \\
\hline COINTEQ01 & -0.83 & 0.05 & -15.82 & 0.00 & -1.24 & 0.08 & -16.47 & 0.00 \\
\hline$D$ ( InENERG) & -0.58 & 0.15 & -3.94 & 0.00 & -0.46 & 0.10 & -4.47 & 0.00 \\
\hline$C$ & 14.93 & 0.94 & 15.88 & 0.00 & 34.70 & 2.14 & 16.20 & 0.00 \\
\hline @TREND & & & & & -0.01 & 0.01 & -0.75 & 0.45 \\
\hline
\end{tabular}

Table 5: Panel cointegration results (Pooled estimation) - InGAP, InENERG

\begin{tabular}{|c|c|c|c|c|c|c|c|c|}
\hline \multicolumn{9}{|c|}{ Panel Fully Modified Least Squares (FMOLS) } \\
\hline \multirow[b]{2}{*}{ Variable } & \multicolumn{4}{|c|}{ Constant } & \multicolumn{4}{|c|}{ Constant and trend } \\
\hline & Coefficient & Std. Error & t-Statistic & Prob. & Coefficient & Std. Error & t-Statistic & Prob. \\
\hline InENERG & 0.05 & 0.06 & 0.89 & 0.37 & -0.02 & 0.06 & -0.43 & 0.67 \\
\hline \multicolumn{9}{|c|}{ Panel Dynamic Least Squares (DOLS) } \\
\hline \multirow{2}{*}{ Variable } & \multicolumn{4}{|c|}{ Constant $(1,1)$} & \multicolumn{4}{|c|}{ Constant and trend $(1,1)$} \\
\hline & Coefficient & Std. Error & t-Statistic & Prob. & Coefficient & Std. Error & t-Statistic & Prob. \\
\hline InENERG & 0.88 & 0.39 & 2.27 & 0.03 & 5.89 & 1.74 & 3.38 & 0.00 \\
\hline \multicolumn{9}{|c|}{ PMG/ARDL (Pooled Mean Group/AR Distributed Lag) - ARDL $(1,1)$} \\
\hline \multirow{3}{*}{ Variable } & \multicolumn{4}{|c|}{ Restricted constant } & \multicolumn{4}{|c|}{ Unrestricted constant } \\
\hline & Coefficient & Std. Error & t-Statistic & Prob. & Coefficient & Std. Error & t-Statistic & Prob. \\
\hline & & & & ong Ru & Equation & & & \\
\hline \multirow[t]{2}{*}{ InENERG } & 0.72 & 0.14 & 5.27 & 0.00 & -0.09 & 0.03 & -2.84 & 0.01 \\
\hline & \multicolumn{8}{|c|}{ Short Run Equation } \\
\hline COINTEQ01 & -0.66 & 0.06 & -10.88 & 0.00 & -0.82 & 0.04 & -18.39 & 0.00 \\
\hline D( InENERG) & 0.48 & 0.23 & 2.09 & 0.04 & -0.88 & 0.21 & 4.24 & 0.00 \\
\hline C & -4.42 & 0.38 & -11.55 & 0.00 & 0.64 & 0.12 & 5.58 & 0.00 \\
\hline @TREND & & & & & -0.01 & 0.01 & -2.38 & 0.02 \\
\hline
\end{tabular}

Results of (pooled) estimation methods indicate that long-run coefficients are statistically significant with positive signs, as we theoretically expect. Results from the equation (1) with standard GDP measure (Table 4) indicate that the long-run coefficients obtained from all estimation methods are positive and strongly significant, varying from 0.70 to 0.82 in the case with constant (only FMOLS providing low positive impact), but are low in the case for constant with trend varying from 0.07 to 0.13 (with PMG/ARDL providing significant negative effect). Hence, it can be concluded that a rise in energy consumption leads to an increase in the green GDP, the coefficients suggesting the relationship that is rather inelastic. The increase of total energy consumption over time did not hamper the growth of green GDP. Zero restrictions on the long-run parameters are tested using the Wald test (available upon request), confirming their statistical significance. Short-run evidence from the PMG/ARDL model is consistent with the long-run relationship (available upon request), which indirectly confirms the homogeneity of the sample. 
Results from the equation (2) with gap GDP measure (Table 5) also indicate the long-run coefficients obtained from estimation methods are positive and strongly significant, varying from 0.72 to 0.87 in the case with constant (again FMOLS providing limited positive impact), however, with the results that are unconvincing in the case for constant with a trend for only DOLS suggesting a significant positive relation of 5.89 (two other methods indicating either insignificant and/or negative impact). Analogously, it can be concluded that a rise in energy consumption leads to a rise in gap GDP measure, i.e. a widening of the gap between the traditional GDP indicator and the green GDP. Once more, zero restrictions on the long-run parameters are tested using the Wald test (available upon request), confirming their statistical significance. Short-run evidence from the PMG/ARDL model is consistent with the long-run relationship, however when scrutinizing on the individual short-run crosssection results (available upon request), we find mixed results regarding the signs of the coefficients, but with error correction coefficients are statistically significant for almost all countries suggesting a slow to moderate speed of convergence.

\section{b) indirect effect}

The results from Pedroni's and Kao's panel cointegration tests (Table 6), from an equation 3, strongly reject the null hypothesis of no cointegration between variables, implicating that there also exists a long-term (indirect) relationship between the green GDP and energy consumption, which can be captured by evaluating how different elements of energy consumption affect the gap between the traditional GDP and the green GDP. Johansen Fisher panel cointegration results varied due to numbers of lags used or due to insufficient data for estimation, thus we could not obtain prudent conclusions.

\begin{tabular}{|c|c|c|c|c|c|c|c|c|}
\hline \multicolumn{9}{|c|}{ Variables: lnGAP, lnFFUEL, lnNGAS, lnOIL, InRENEW } \\
\hline \multirow{2}{*}{$\begin{array}{l}\text { Pedroni residual } \\
\text { cointegration test }\end{array}$} & \multicolumn{4}{|c|}{ Intercept } & \multicolumn{4}{|c|}{ Intercept and trend } \\
\hline & Statistic & Prob. & $\begin{array}{l}\text { Weighted } \\
\text { Statistic }\end{array}$ & Prob. & Statistic & Prob. & $\begin{array}{l}\text { Weighted } \\
\text { Statistic }\end{array}$ & Prob. \\
\hline Panel v-Statistic & -1.85 & 0.97 & -3.29 & 0.99 & -2.69 & 0.99 & -5.15 & 1.00 \\
\hline Panel rho-Statistic & 5.10 & 1.00 & 5.05 & 1.00 & 7.02 & 1.00 & 6.94 & 1.00 \\
\hline Panel PP-Statistic & -2.47 & 0.01 & -7.63 & 0.00 & -0.69 & 0.24 & -10.25 & 0.00 \\
\hline Panel ADF-Statistic & -2.61 & 0.01 & -5.58 & 0.00 & - & - & - & - \\
\hline Group rho-Statistic & 7.52 & 1.00 & & & 8.55 & 1.00 & & \\
\hline Group PP-Statistic & -11.52 & 0.00 & & & -18.54 & 0.00 & & \\
\hline Group ADF-Statistic & -4.69 & 0.00 & & & - & - & & \\
\hline $\begin{array}{c}\text { Kao residual } \\
\text { cointegration test }\end{array}$ & \multicolumn{4}{|c|}{ t-Statistic } & \multicolumn{4}{|c|}{ Prob. } \\
\hline $\mathrm{ADF}$ & \multicolumn{4}{|c|}{-3.34} & \multicolumn{4}{|c|}{0.00} \\
\hline
\end{tabular}

The following table presents the panel cointegration results from FMOLS and DOLS estimation methods between the green GDP and selected factors of energy consumption (by products), testing the characteristics of the long-run linear cointegration relations. Reasonable PMG/ARDL estimations could not be obtained; therefore, we opted not to apply this method.

Table 7: Panel cointegration results (Pooled estimation) - InGAP vs. energy consumption by products

\begin{tabular}{|c|c|c|c|c|c|c|c|c|}
\hline \multicolumn{9}{|c|}{ Panel Fully Modified Least Squares (FMOLS) } \\
\hline \multirow[b]{2}{*}{ Variable } & \multicolumn{4}{|c|}{ No constant no trend } & \multicolumn{4}{|c|}{ Constant and trend } \\
\hline & Coefficient & Std. Error & t-Statistic & Prob. & Coefficient & Std. Error & t-Statistic & Prob. \\
\hline lnFFUEL & 0.16 & 0.05 & 3.13 & 0.00 & 0.08 & 0.06 & 1.37 & 0.17 \\
\hline $\operatorname{lnNGAS}$ & -0.29 & 0.05 & -5.70 & 0.00 & 0.26 & 0.11 & 2.33 & 0.02 \\
\hline $\operatorname{lnOIL}$ & -0.09 & 0.09 & -1.03 & 0.31 & 0.09 & 0.22 & 0.41 & 0.68 \\
\hline lnRENEW & 0.24 & 0.09 & 2.85 & 0.01 & 0.03 & 0.14 & 0.21 & 0.84 \\
\hline \multicolumn{9}{|c|}{ Panel Dynamic Least Squares (DOLS) } \\
\hline \multirow{2}{*}{ Variable } & \multicolumn{4}{|c|}{ No constant no trend $(0,0)$} & \multicolumn{4}{|c|}{ Constant and trend $(0,0)$} \\
\hline & Coefficient & Std. Error & $\mathrm{t}$-Statistic & Prob. & Coefficient & Std. Error & $\mathrm{t}$-Statistic & Prob. \\
\hline lnFFUEL & 0.12 & 0.05 & 2.11 & 0.04 & 0.32 & 0.09 & 3.67 & 0.00 \\
\hline
\end{tabular}




\begin{tabular}{c|cccccccc}
$\operatorname{lnNGAS}$ & -0.25 & 0.06 & -4.01 & 0.00 & -0.11 & 0.16 & -0.74 & 0.47 \\
$\operatorname{lnOIL}$ & -0.03 & 0.11 & -0.26 & 0.79 & -0.09 & 0.83 & 0.24 & 0.00 \\
$\operatorname{lnRENEW}$ & 0.17 & 0.11 & 1.50 & 0.14 & 0.18 & 0.17 & 1.07 & 0.29 \\
\hline \multicolumn{7}{c}{ Source: Authors' calculations. }
\end{tabular}

Results from the equation (3) that captures the indirect effect (Table 7) indicate long-run coefficients that are most significant with expected signs. Solid fossil fuel coefficients are positive and strongly significant (except in the case with constant and trend within FMOLS where it is statistically insignificant), varying from 0.8 to 0.32 suggesting that an increase in fossil fuel consumption widens the gap between the GDP indicator and Green GDP. Such results are expected for the consumption of fossil fuels that could be the drivers of traditional GDP measures. However, their environmental implications could be a limiting factor for green GDP growth. However, natural gas coefficients are negative and strongly significant (except in the case with constant and trend within FMOLS where it is positive) varying from -0.11 to -0.29 , implying that an increase in natural gas consumption decreases the gap GDP measure. Since natural gas consumption generates less environmental pollution, it can be represented as a strong driver of green GDP development. Oil and petroleum coefficients are mostly statistically insignificant. However, its high positive correlation with green GDP and moderate negative correlation with gap GDP measure suggests that the rise of oil and petroleum consumption could be increasing the difference between the traditional and green GDP (see correlation matrix and scatter diagram in the Appendix). The same problem arises when observing renewable and biofuel consumption, which displays positive and insignificant coefficients, but with high positive correlation with green GDP and weak negative correlation with gap GDP measure (with an inconclusive display from the scatter diagram), it could have an opposite implication, therefore curtailing that gap.

Our empirical models provide valuable insight into the background and the relationship between the green GDP and energy consumption for European countries, suggesting that an increase in total energy consumption leads to an increase in green GDP variables (as it also consists of standard factors of economic growth). However, it also deepens the difference between the traditional GDP measure and green GDP measure (implying that it hampers the green development of an economy). When decomposing total energy consumption in its integral elements (consumption by product) we find that an increase in consumption of energy in sectors that are environmentally more damaging (like solid fossil fuels and oil and petroleum) emphasize the gap between the traditional and green GDP, but that an increase in more environmentally 'friendly' consumption (like natural gas and renewables and biofuels) curtails and alleviate that gap. These models illustrate when it comes to green GDP, green growth and green economy, the contribution of natural gas consumption should have a greater role in promoting economic growth for European countries and that this consumption of, for example, fossil fuels and oil, which bring a substantial proportion of the green cost, should be incorporated with sound environmental strategy.

\section{Conclusion}

In our analysis, we used two models to observe the effect of energy consumption on GDP and green GDP. In one model, we look at the relationship between total energy consumption and GDP growth, hence the green GDP, while in the other model, we concentrated on separate variables related to different energy sources, from which we then analyzed their individual impacts on the difference between GDP and green GDP.

The results confirm theoretical expectations as we provided evidence that an increase in energy consumption affects an increase in GDP and green GDP. However, the second part of the analysis confirmed that solid fuels and oil have a much greater impact on the difference between green GDP and GDP than renewable resources and natural gas, which are a much cleaner form of energy source. These results coincide with the results of other research related to green GDP, including (Al-mulali, 2014), that displayed a clear link between GDP growth and energy consumption. Other studies that provided similar results, like (Vaghefi, Siwar, and Aziz, 2015 or Wang, He and Zeng, 2014), also provided similar thoughts on the structure and system of designing research patterns on green GDP.

In general, we can accept the main hypothesis as we provide enough evidence to show that energy consumption has an important effect on green GDP development. Though the paper deals with relatively short time series (data (un)availability is a major obstacle in achieving more (time) extensive research on a crosscountry base for which most of the data needed for calculation of the green GDP are published irregularly) and basic empirical modeling (without a strong background in theory), we are of the thought that future research endeavors should include reassessments of the influence of specific elements of energy consumption on green growth and economic sustainability. Our approach and deductions made above present only our research logic and could/should be subject to revision in the future. Future research patterns related to this topic should be pointed towards expanding the definition of green GDP with new variables, which will take in detail all types of pollution produced by the economic system or the economy of a country, and all forms of consumption of 
natural resources, and calculate the negative impact on the health of the inhabitants of a particular country, which then represents an indirect or direct cost to that economy.

\section{References}

Al-mulali, U. (2014). GDP growth - energy consumption relationship: Revisited. International Journal of Energy Sector Management. 8(3).

Breitung, J. (2000). The Local Power of Some Unit Root Tests for Panel Data. In B. Baltagi (ed.), Advances in Econometrics, Vol. 15: Non-stationary Panels, Panel Cointegration, and Dynamic Panels, Elsevier Science Inc.

Breitung, J. and Pesaran, H. M. (2005). Unit Roots and Cointegration in Panels. CESIFO Working Paper No. 1565, CESifo Group Munich.

Choi, I. (2001). Unit Root Tests for Panel Data. Journal of International Money and Finance, 20(2), pp. 249272.

Di Lorio, F. and Fachin, S. (2011) A Panel Cointegration study of the long-run relationship between Savings and Investments in the OECD economies, 1970-2007. Working Paper No. 3, Department of Treasury of the Italian Ministry of Economy and Finance.

Eurostat (2020). Available at: https://ec.europa.eu/info/departments/eurostat-european-statistics_en.

Faisal, F., Tursoy, T., Resatoglu, N.G. \& Berk, N. (2018). Electricity consumption, economic growth, urbanization and trade nexus: empirical evidence from Iceland, Economic Research-Ekonomska Istraživanja, 31(1), 664-680, https://doi.org/10.1080/1331677X.2018.1438907.

Gavurova, B., Perzelova, I. and Bencoova, B., (2016). Economic aspects of renewable energy use-application of support schemes based on a particular biogas plant in Slovakia. Acta Montanistica Slovaca, 21(3).

Harnphatananusorn, S., Santipolvut, S. and Sonthi, C. (2019). Concepts and empirical calculation of the green GDP for Thailand. International Journal of Green Economics, 13(1), p.68.

Hongxian, X. 2018. Influences Energy Consumption has on Green GDP Growth in China. IOP Conference Series: Earth and Environmental Science. 113(1).

Im, K., Pesaran, M. and Shin, Y., (2003). Testing for unit roots in heterogeneous panels. Journal of Econometrics, 115(1), pp.53-74.

Kao, C., (1999). Spurious regression and residual-based tests for cointegration in panel data. Journal of Econometrics, 90(1), pp.1-44.

Kao, C. and Chiang, M-H. (2000). On the Estimation and Inference of a Cointegrated Regression in Panel Data. In B. Baltagi (ed.), Advances in Econometrics, Vol. 15: Non-stationary Panels, Panel Cointegration, and Dynamic Panels, Elsevier Science Inc.

Kovács, F. (2007). World energy demands and coal reserves. Acta Montanistica Slovaca Rocník, 12(3), $276-283$.

Levin, A., Lin, C. and James Chu, C. (2002). Unit root tests in panel data: asymptotic and finite-sample properties. Journal of Econometrics, 108(1), pp.1-24.

Maddala, G. and Wu, S. (1999). A Comparative Study of Unit Root Tests with Panel Data and a New Simple Test. Oxford Bulletin of Economics and Statistics, 61(S1), pp.631-652.

Malaczewski, M. (2018). Complementarity between energy and physical capital in a simple model of economic growth, Economic Research-Ekonomska Istraživanja, 31(1), 1169-1184, https://doi.org/ 10.1080/1331677X.2018.1456353

Pedroni, P., 1999. Critical Values for Cointegration Tests in Heterogeneous Panels with Multiple Regressors. Oxford Bulletin of Economics and Statistics, 61(s1), pp.653-670.

Pedroni, P. (2000). Fully Modified OLS for Heterogeneous Cointegrated Panels In B. Baltagi (ed.), Advances in Econometrics, Vol. 15: Non-stationary Panels, Panel Cointegration, and Dynamic Panels, Elsevier Science Inc.

Pedroni, P. (2001). Purchasing Power Parity Tests in Cointegrated Panels. Review of Economics and Statistics, 83(4), pp.727-731.

Pedroni, P. (2004). Panel cointegration: asymptotic and finite sample properties of pooled time series tests with an application to the ppp hypothesis. Econometric Theory, 20(03).

Pesaran, M., Shin, Y. and Smith, R. (1999). Pooled Mean Group Estimation of Dynamic Heterogeneous Panels. Journal of the American Statistical Association, 94(446), pp.621-634.

Phillips, P. and Hansen, B. (1990). Statistical Inference in Instrumental Variables Regression with I(1) Processes. The Review of Economic Studies, 57(1), p.99.

Phillips, P. and Moon, H. (1999). Linear Regression Limit Theory for Nonstationary Panel Data. Econometrica, 67(5), pp.1057-1111. 
Rahman, Z. U., Cai, H., Khattak, SI, \& Hasan, M.M. (2019). Energy production-income-carbon emissions nexus in the perspective of NAFTA and BRIC nations: a dynamic panel data approach, Economic ResearchEkonomska Istraživanja, 32(1), 3384-3397, https://doi.org/10.1080/1331677X.2019.1660201.

Saikkonen, P. (1992). Estimation and Testing of Cointegrated Systems by an Autoregressive Approximation. Econometric Theory, 8(01), pp.1-27.

Sokolovska, I., \& Kešeljević, A. (2019). Does sustainability pay off? A multi-factor analysis on regional DJSI and renewable stock indices, Economic Research-Ekonomska Istraživanja, 32(1), 423-439, https://doi.org/10.1080/1331677X.2018.1550002

Stjepanović, S., Tomić, D. and Škare, M. (2019). Green GDP: an analysis for developing and developed countries. E+M Ekonomie a Management, 22(4), pp.4-17.

Stjepanović, S. Tomić, D. and Škare, M. (2017). A new approach to measuring Green GDP: A Cross-country analysis. Enterpreneurship and Sustainability Issues, 4(4).

Stock, J.H. and Watson, M. (1993). A Simple Estimator Of Cointegrating Vectors In Higher Order Integrated Systems. Econometrica, 61(4), pp. 783-820.

Škare, M., Benazić, M. and Tomić, D. (2016). On the neutrality of money in CEE (EU member) states: A panel cointegration analysis. Acta Oeconomica, 66(3), pp. 393-418.

Tomić, D. (2020). The perspective of Green GDP in growth modelling. 52nd International Scientific Conference on Economic and Social Development. Porto, Portugal, April 16-17.

Vaghefi, N., Siwar, C. and Aziz, S. (2015). Green GDP and Sustainable Development in Malaysia. Current World Environment, 10(1), pp.01-08.

Wang, W., He, E. and Zheng, X. (2014). Construction of Green GDP Accounting System. Advanced Materials Research, 971-973, pp.2301-2304.

Yazdi, S.K., \& Dariani, A.G. (2019). CO2 emissions, urbanization and economic growth: evidence from Asian countries, Economic Research-Ekonomska Istraživanja, 32(1), 510-530, https://doi.org/ 10.1080/1331677X.2018.1556107 


\section{Appendix}

Table 8. Correlation matrix

\begin{tabular}{|c|c|c|c|c|c|c|}
\hline Correlations & InGGDP & InGAP & InFFUEL & InNGAS & $\operatorname{lnOIL}$ & InRENEW \\
\hline InGGDP & 1 & -0.45 & 0.60 & 0.83 & 0.97 & 0.78 \\
\hline InGAP & -0.45 & 1 & -0.09 & -0.49 & -0.46 & -0.23 \\
\hline InFFUEL & 0.60 & -0.09 & 1 & 0.61 & 0.66 & 0.60 \\
\hline InNGAS & 0.83 & -0.49 & 0.61 & 1 & 0.84 & 0.69 \\
\hline $\operatorname{lnOIL}$ & 0.97 & -0.46 & 0.66 & 0.84 & 1 & 0.80 \\
\hline InRENEW & 0.78 & -0.23 & 0.60 & 0.69 & 0.80 & 1 \\
\hline
\end{tabular}

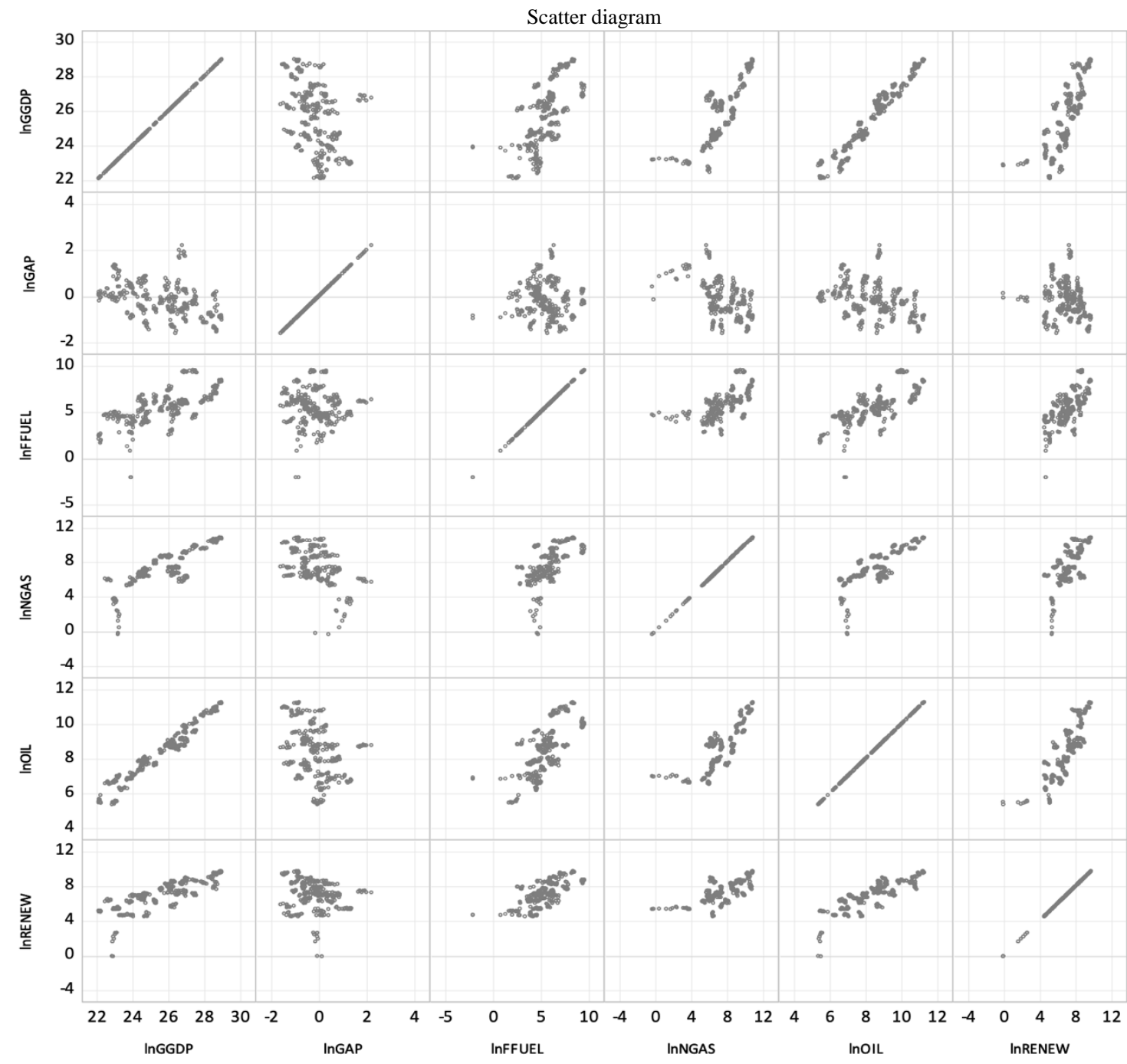

Source: Authors' calculations. 